\title{
Actinophytocola oryzae gen. nov., sp. nov., isolated from the roots of Thai glutinous rice plants, a new member of the family Pseudonocardiaceae
}

\author{
Chantra Indananda, ${ }_{1} \dagger$ Atsuko Matsumoto, ${ }^{2}$ Yuki Inahashi, ${ }^{2}$ \\ Yoko Takahashi, ${ }^{2}$ Kannika Duangmal $^{3}$ and Arinthip Thamchaipenet ${ }^{1}$ \\ ${ }^{1}$ Department of Genetics, Faculty of Science, Kasetsart University, Chatuchak, Bangkok 10900, \\ Thailand \\ ${ }^{2}$ Kitasato Institute for Life Sciences, Kitasato University, 5-9-1 Shirokane, Minato-ku, \\ Tokyo 108-8641, Japan \\ ${ }^{3}$ Department of Microbiology, Faculty of Science, Kasetsart University, Chatuchak, Bangkok 10900, \\ Thailand
}

Correspondence Arinthip Thamchaipenet arinthip.t@ku.ac.th
The family Pseudonocardiaceae was firstly described by Embley et al. (1988) and its description was emended by Stackebrandt et al. (1997) on the basis of 16S rRNA gene sequence analysis. The family currently comprises 16 genera with validly published names, including Actinoalloteichus (Tamura et al., 2000), Actinomycetospora (Jiang et al., 2008), Allokutzneria (Labeda \& Kroppenstedt, 2008), Amycolatopsis (Lechevalier et al., 1986), Crossiella (Labeda, 2001), Goodfellowiella (Labeda et al., 2008), Kibdelosporangium (Shearer et al., 1986), Kutzneria (Stackebrandt et al., 1994), Prauserella (Kim \& Goodfellow, 1999), Pseudonocardia (Henssen, 1957), Saccharomonospora (Nonomura \& Ohara, 1971), Saccharopolyspora (Lacey \& Goodfellow, 1975), Sciscionella (Tian et al., 2009), Streptoalloteichus (Tomita et al., 1987), Thermobispora (Wang et al., 1996) and

tPresent address: Department of Biology, Faculty of Science, Burapha University, Chonburi 20131, Thailand.

The GenBank/EMBL/DDBJ accession number for the 16S rRNA gene sequence of Actinophytocola oryzae GMKU $367^{\top}$ is EU420070.
Thermocrispum (Korn-Wendisch et al., 1995). During the search for novel actinomycetes from varieties of local Thai rice plant cultivars, an endophytic actinomycete, strain GMKU $367^{\mathrm{T}}$, was isolated. Identification and characterization of strain GMKU $367^{\mathrm{T}}$ and its placement in the family Pseudonocardiaceae as a representative of a novel species in a new genus are reported here.

Strain GMKU $367^{\mathrm{T}}$ was isolated from roots of Thai glutinous rice plants (Oryza sativa L. 'RD6') collected from Pathum Thani Rice Research Center, Pathum Thani province, Thailand. The excised roots were surfacesterilized using serial treatments of $95 \%$ ethanol for $10 \mathrm{~min}, 1 \%$ sodium hypochlorite for $15 \mathrm{~min}$ and $10 \%$ $\mathrm{NaHCO}_{3}$ for $10 \mathrm{~min}$. The roots were then ground and spread onto starch-casein agar (Küster \& Williams, 1964) supplemented with $2.5 \mathrm{U}$ penicillin $\mathrm{G} \mathrm{ml}^{-1}$ and $50 \mathrm{mg}$ cycloheximide $\mathrm{ml}^{-1}$. Colonies of endophytic actinomycetes appeared on the medium after incubation at $30{ }^{\circ} \mathrm{C}$ for $4-5$ weeks. Cells of strain GMKU $367^{\mathrm{T}}$ were isolated and purified on mannitol-soy agar (Hobbs et al., 1989). The 
pure culture was maintained as a $20 \%$ glycerol suspension at $-80{ }^{\circ} \mathrm{C}$ or as lyophilized cells for long-term preservation.

To study cultural characteristics, strain GMKU $367^{\mathrm{T}}$ was grown on several media, namely yeast extract-malt extract agar (ISP 2), oatmeal agar (ISP 3), inorganic salts-starch agar (ISP 4), glycerol-asparagine agar (ISP 5), oatmealnitrate agar (JCM medium 52) and 1/10 yeast extractstarch agar. Mycelium and soluble pigment colours were determined by comparison with colour chips from the Color Harmony Manual (Jacobson et al., 1958). In order to examine morphological characteristics, strain GMKU $367^{\mathrm{T}}$ was grown on humic acid-vitamin agar (HV medium; Hayakawa \& Nonomura, 1987), tap water agar and sucrose-nitrate agar for 8 weeks at $27^{\circ} \mathrm{C}$; spore morphology was then observed using light and scanning electron microscopy (JSM 5600; JEOL).

Physiological characteristics of strain GMKU $367^{\mathrm{T}}$ were determined as follows. The temperature range for growth was determined on ISP 2 in a temperature gradient incubator. Reduction of nitrate and production of melanin pigments were determined according to Shirling \& Gottlieb (1966). Catalase and oxidase activities were determined with a $3 \%(\mathrm{v} / \mathrm{v})$ hydrogen peroxide solution and $1 \%$ tetramethyl-p-phenylenediamine solution, respectively. Hydrolysis of starch was determined as described by Gordon et al. (1974). Utilization of carbohydrates as sole carbon sources was tested by using ISP 4 without soluble starch, since strain GMKU $367^{\mathrm{T}}$ did not grow on carbon utilization medium (ISP 9) (Shirling \& Gottlieb, 1966). Utilization of benzoate, citrate, xanthine and hypoxanthine and acid production from carbohydrates were assessed according to the methods of Gordon et al. (1974).

To analyse chemotaxonomic characteristics, biomass samples were prepared by growing the strain in yeast extract-glucose broth at $27{ }^{\circ} \mathrm{C}$ for 7 days and then freezedrying the cells. Isomers of diaminopimelic acid in the cell wall were determined by TLC according to the method of Hasegawa et al. (1983). Peptidoglycan of cell walls was isolated and purified according to the method of Schleifer \& Kandler (1972). Purified samples were hydrolysed (Becker et al., 1965) and analysed by TLC (Hasegawa et al., 1983) and the Pico Tag method using HPLC (Waters). The cell-wall acyl type was analysed by using the method of Uchida \& Aida (1984). Whole-cell sugars were analysed according to the method of Becker et al. (1965). Menaquinones were extracted and purified by the method of Collins et al. (1977) and isoprene units were analysed by HPLC using a JASCO 802-SC chromatograph equipped with a Shiseido CAPCELL PAK C18 column (Tamaoka et al., 1983). Mycolic acids were detected by TLC using the method of Tomiyasu (1982). The cellular fatty acid composition was analysed by TechnoSuruga Laboratory (Japan) according to the instructions of the Microbial Identification System (MIDI) by GC (model HP6890; Hewlett Packard) (Sasser, 1990). DNA G + C content was determined by HPLC as described by Tamaoka \& Komagata (1984).

Morphological analysis of cells of strain GMKU $367^{\mathrm{T}}$ revealed cylindrical spores on aerial mycelium, but no sporangium-like structures or fragmentation of substrate mycelium (Fig. 1). Good growth was observed on oatmeal agar and oatmeal-nitrate agar. The cell-wall amino acids of strain GMKU $367^{\mathrm{T}}$ contained meso-diaminopimelic acid, alanine and glutamic acid in a molar ratio of $1.0: 1.2: 1.0$. The peptidoglycan was of the acetyl type. No mycolic acids were detected. Whole-cell sugars were arabinose, galactose, mannose, rhamnose and ribose. The major fatty acids (above $10 \%$ ) were iso- $\mathrm{C}_{16: 0}(40.24 \%)$, iso- $\mathrm{C}_{15: 0}(12.17 \%)$ and $\mathrm{C}_{16: 0}(10.39 \%)$; minor fatty acids $(3-10 \%)$ were iso$\mathrm{C}_{16: 0} 2-\mathrm{OH}(7.67 \%), \mathrm{C}_{15: 0}(3.39 \%)$, iso- $\mathrm{C}_{16: 1}(3.27 \%)$ and iso- $\mathrm{C}_{17: 0}(3.15 \%)$. MK-9 $\left(\mathrm{H}_{4}\right)$ was the only diagnostic menaquinone. The polar phospholipids were phosphatidylethanolamine and hydroxyphosphatidylethanolamine. The DNA G+C content of strain GMKU $367^{\mathrm{T}}$ was $71.1 \mathrm{~mol} \%$.

The 16S rRNA gene from strain GMKU $367^{\mathrm{T}}$ was amplified and sequenced. Total DNA of strain GMKU $367^{\mathrm{T}}$ was extracted and purified according to Kieser et al. (2000). PCR amplification of the 16S rRNA gene was carried out using primers and PCR conditions described previously (Kataoka et al., 1997). The almost-complete 16S rRNA gene sequence of strain GMKU $367^{\mathrm{T}}$ was determined by direct sequencing of the PCR product (1444 bp). Initially, the sequence was compared with those available in GenBank; comparisons revealed that strain GMKU $367^{\mathrm{T}}$ belonged to the suborder Pseudonocardineae. The nearly complete 16S rRNA gene sequence of strain GMKU $367^{\mathrm{T}}$ was aligned with those of representative type strains of members of the other 23 genera of the suborder Pseudonocardineae using CLUSTAL_X version 2 (Larkin et al., 2007). Phylogenetic trees were deduced using the neighbour-joining (Saitou \& Nei, 1987), maximum-likelihood

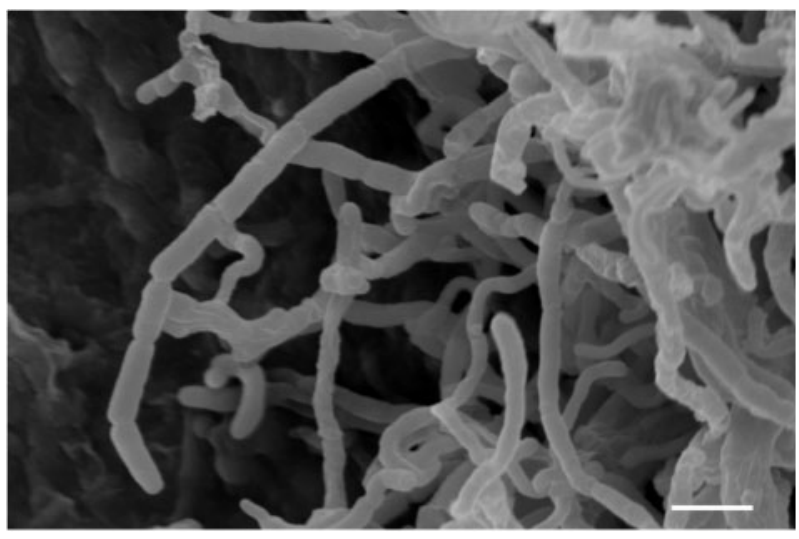

Fig. 1. Scanning electron micrograph of growth of strain GMKU $367^{\top}$ on HV medium after incubation at $27^{\circ} \mathrm{C}$ for 8 weeks. Bar, $2 \mu \mathrm{m}$. 
(Felsenstein, 1981) and maximum-parsimony (Eck \& Dayhoff, 1966) methods and constructed by NJPLOT (Perrière \& Gouy, 1996), PHYLIP 3.68 and MEGA4 (Tamura et al., 2007), respectively. The resultant neighbour-joining tree topology was evaluated by levels of bootstrap support based on analysis of 1000 resampled datasets (Felsenstein, 1985). Evolutionary distances were computed by using Kimura's two-parameter method (Kimura, 1980).

On the basis of $16 \mathrm{~S}$ rRNA gene sequence analysis, strain GMKU $367^{\mathrm{T}}$ showed the highest sequence similarity to Kibdelosporangium aridum subsp. aridum DSM $43828^{\mathrm{T}}$ (95.5\%), Streptoalloteichus hindustanus IFO $15115^{\mathrm{T}}$ (95.4\%), Actinokineospora enzanensis IFO $16517^{\mathrm{T}}$ (95.4\%) and Amycolatopsis nigrescens $\mathrm{CSC} 17 \mathrm{Ta}-90^{\mathrm{T}}$ (95.3\%), belonging to the suborder Pseudonocardineae. Sequence similarities higher than $95 \%$ were not observed between strain GMKU $367^{\mathrm{T}}$ and any other type strains of species in the suborder Pseudonocardineae. Although high sequence similarity was found between strain GMKU $367^{\mathrm{T}}$ and members of the genera Actinokineospora and Streptoalloteichus, which belong to the family Actinosynnemataceae, strain GMKU $367^{\mathrm{T}}$ was phylogenetically separate from both genera (Fig. 2). It is evident from the phylogenetic tree that strain GMKU $367^{\mathrm{T}}$ formed a distinct subclade within members of the family Pseudonocardiaceae and was recovered as a sister group of the genus Kibdelosporangium (Fig. 2). Although the bootstrap value of the neighbour-joining tree at the corresponding node was moderate ( $43 \%$ ), the close relationship was solidly supported by maximum-likelihood and maximum-parsimony trees (Fig. 2).

The morphological and chemotaxonomic characteristics of strain GMKU $367^{\mathrm{T}}$ that distinguish it from closely related members in the family Pseudonocardiaceae are shown in Table 1. Scanning electron microscopic observations of strain GMKU $367^{\mathrm{T}}$ showed cylindrical spores on aerial mycelium, but did not reveal sporangium-like structures or fragmentation of substrate mycelium (Fig. 1), which enables it to be differentiated from members of the genus Kibdelosporangium, the nearest neighbouring genus, and phylogenetically closely related genera. The phospholipid profile of strain GMKU $367^{\mathrm{T}}$ was clearly distinct from those of members of closely related genera as it contained both phosphatidylethanolamine and hydroxyphosphatidylethanolamine, but lacked phosphatidylcholine, phosphatidylglycerol, diphosphatidylglycerol and phosphatidylinositol. The fatty acid profile of strain GMKU $367^{\mathrm{T}}$ was

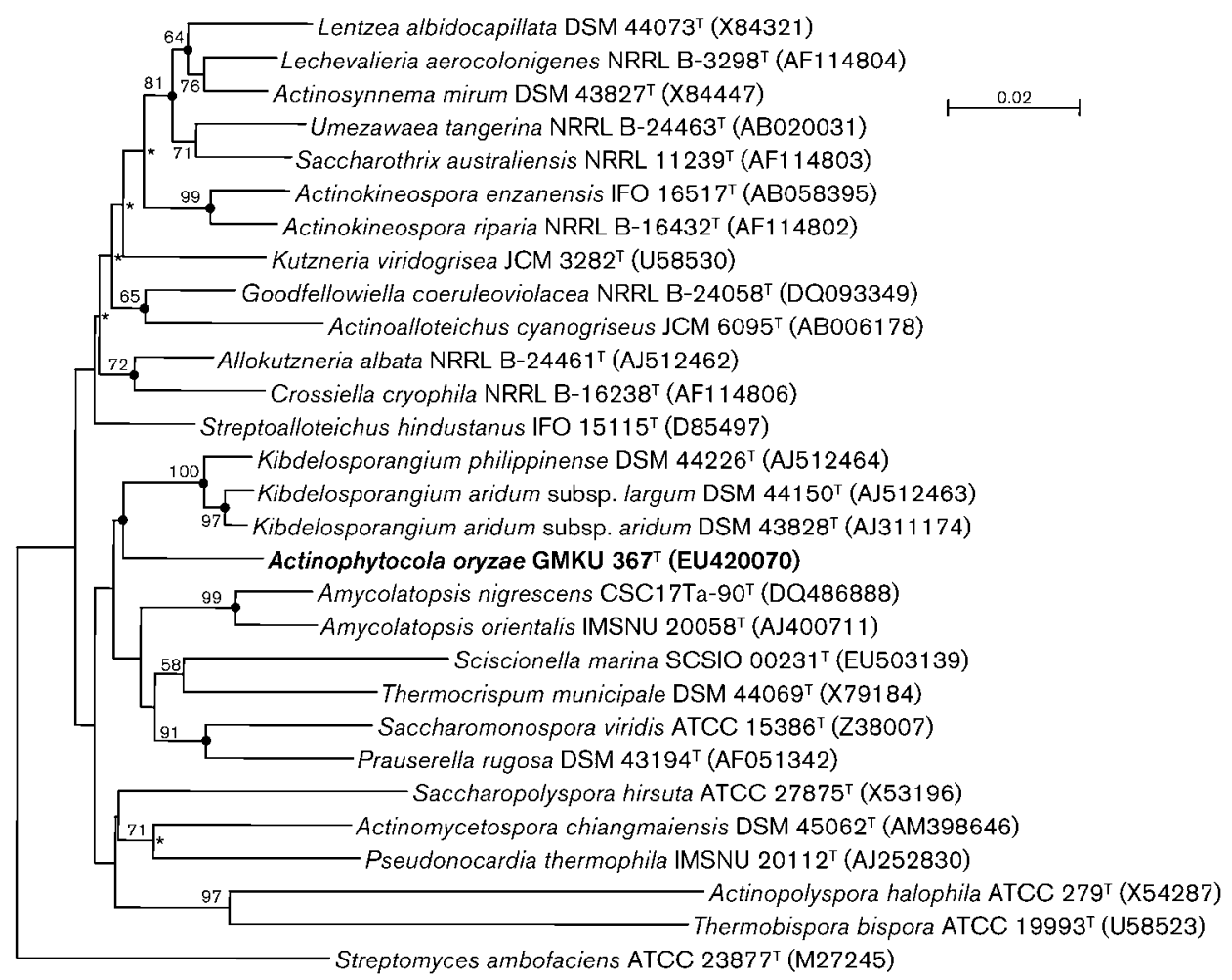

Fig. 2. Phylogenetic tree for taxa of the suborder Pseudonocardineae constructed using the neighbour-joining method based on almost complete 16S rRNA sequences to display the taxonomic position of the strain GMKU $367^{\top}$. Streptomyces ambofaciens ATCC $23877^{\top}$ was used as the root organism. Numbers at nodes indicate levels of bootstrap support (\%) based on neighbour-joining analysis of 1000 resampled datasets; only values above $50 \%$ are shown. Solid circles indicate nodes that were also recovered from maximum-likelihood and maximum-parsimony trees; asterisks indicate nodes that were recovered from maximum-parsimony trees. Bar, 0.02 substitutions per site. 
Table 1. Morphological and chemotaxonomic profiles of Actinophytocola gen. nov. and phylogenetically related genera

Genera: 1, Actinophytocola gen. nov. (data from this study); 2, Amycolatopsis (Lechevalier et al., 1986; Lee \& Hah, 2001); 3, Kibdelosporangium (Shearer et al., 1986; Labeda \& Kroppenstedt, 2008); 4, Pseudonocardia (Warwick et al., 1994; Reichert et al., 1998; Huang et al., 2002; Park et al., 2008); 5, Saccharopolyspora (Korn-Wendisch et al., 1989); 6, Thermocrispum (Korn-Wendisch et al., 1995). -, Absent; +, present; v, variable.

\begin{tabular}{|c|c|c|c|c|c|c|}
\hline Character & 1 & 2 & 3 & 4 & 5 & 6 \\
\hline \multicolumn{7}{|l|}{ Morphology } \\
\hline Aerial hyphae & + & $\mathrm{v}$ & + & $\mathrm{v}$ & + & + \\
\hline Fragmented mycelium & - & + & + & $\mathrm{v}$ & + & - \\
\hline $\begin{array}{l}\text { Sporangium-like } \\
\text { structures }\end{array}$ & - & - & + & - & - & + \\
\hline Whole-cell sugars ${ }^{\star}$ & $\begin{array}{c}\text { Ara, Gal, Man, } \\
\text { Rha, Rib }\end{array}$ & Ara, Gal & Ara, Gal, (Mad) & Ara, Gal & Ara, Gal & $\begin{array}{r}\text { Ara, (Gal), } \\
\text { Glc, Man }\end{array}$ \\
\hline Phospholipids $\dagger$ & $\underline{\mathrm{PE}}, \mathrm{OH}-\mathrm{PE}$ & 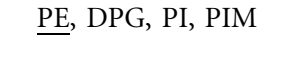 & $\begin{array}{l}\text { PE, PME, PG, PI, } \\
\text { PIM, DPG }\end{array}$ & $\underline{\mathrm{PC}}$ or $\underline{\mathrm{PE}}, \mathrm{PME}$ & $\begin{array}{c}\text { PC, PE, lyso-PE, PME, } \\
\text { DPG, PI, PG }\end{array}$ & $\frac{\mathrm{PE}, \mathrm{OH}-}{\mathrm{PE}, \mathrm{PI}}$ \\
\hline Major menaquinone(s) & $\mathrm{MK}-9\left(\mathrm{H}_{4}\right)$ & MK-9 $\left(\mathrm{H}_{2}\right)$, MK-9 $\left(\mathrm{H}_{4}\right)$ & MK-9 $\left(\mathrm{H}_{4}\right)$ & $\begin{array}{c}\text { MK-8 }\left(\mathrm{H}_{4}\right) \text { or } \\
\text { MK- } 9\left(\mathrm{H}_{0}\right)\end{array}$ & MK-9 $\left(\mathrm{H}_{4}\right)$ & $\mathrm{MK}-9\left(\mathrm{H}_{4}\right)$ \\
\hline Major fatty acids & $\begin{array}{c}\mathrm{i}-\mathrm{C}_{15: 0}, \mathrm{i}-\mathrm{C}_{16: 0} \\
\mathrm{C}_{16: 0}\end{array}$ & $\begin{array}{l}\mathrm{i}-\mathrm{C}_{15: 0,}, \mathrm{i}-\mathrm{C}_{16: 0} \\
\text { ai- } \mathrm{C}_{17: 0}, \mathrm{C}_{17: 0}\end{array}$ & $\begin{array}{c}\text { ai- } C_{15: 0,} \text { i- } C_{16: 0} \\
\text { ai- } C_{17: 0}\end{array}$ & $\mathrm{i}-\mathrm{C}_{16: 0}, \mathrm{C}_{16: 0}$ & $\begin{array}{l}\mathrm{i}-\mathrm{C}_{15: 0}, \mathrm{i}-\mathrm{C}_{16: 0} \\
\mathrm{i}-\mathrm{C}_{17: 0,}, \text { ai- } \mathrm{C}_{17: 0}\end{array}$ & $\mathrm{i}-\mathrm{C}_{16: 0}$ \\
\hline $\begin{array}{l}\text { DNA G }+ \text { C content } \\
(\mathrm{mol} \%)\end{array}$ & 71.1 & $66-69$ & 66 & $68-79$ & $70.4-71.5$ & $69-73$ \\
\hline
\end{tabular}

*Ara, Arabinose; Gal, galactose; Glc, glucose; Mad, madurose; Man, mannose; Rha, rhamnose; Rib, ribose. Sugars given in parentheses are present in trace amounts.

$\dagger$ DPG, Diphosphatidylglycerol; PC, phosphatidylcholine; PE, phosphatidylethanolamine; OH-PE, PE with hydroxyl fatty acid; lyso-PE, PE with one fatty acid chain missing from the glycerol backbone; PG, phosphatidylglycerol; PI, phosphatidylinositol; PIM, phosphatidylinositol mannosides; PME, phosphatidylmonomethylethanolamine. Underlined components represent the diagnostic phospholipids according to Lechevalier et al. (1977).

also dissimilar from those of members of phylogenetically closely related genera.

On the basis of significant differences in phylogenetic data, chemotaxonomic properties and morphological analyses, strain GMKU $367^{\mathrm{T}}$ represents a novel species in a new genus in the family Pseudonocardiaceae, for which the name Actinophytocola oryzae gen. nov., sp. nov. is proposed.

\section{Description of Actinophytocola gen. nov.}

Actinophytocola [Ac.ti.no.phy.to' co.la. Gr. n. actis, actinos a ray, beam; Gr. n. phuton a plant; L. masc. suff. -cola (from L. n. incola) a dweller, inhabitant; N.L. masc. n. Actinophytocola actinobacterial dweller inside a plant].

Aerobic, Gram-stain-positive, non-acid-fast, non-motile actinomycetes. Have non-fragmented substrate mycelium and, on some media, aerial mycelium is produced. Cylindrical spores are produced on aerial mycelium, but no sporangium-like structures are observed. Good growth occurs at $18-28{ }^{\circ} \mathrm{C}$ and on oatmeal agar and oatmealnitrate agar. The cell wall contains meso-diaminopimelic acid, alanine, glutamic acid and acetylated muramic acid. The whole-cell sugars are arabinose, galactose, mannose, rhamnose and ribose. Mycolic acids are absent. The major fatty acids are iso- $\mathrm{C}_{15: 0}$, iso- $\mathrm{C}_{16: 0}$ and $\mathrm{C}_{16: 0}$. The diagnostic menaquinone is MK- $9\left(\mathrm{H}_{4}\right)$. The polar phospholipids are phosphatidylethanolamine and hydroxyphos- phatidylethanolamine. The type species is Actinophytocola oryzae.

\section{Description of Actinophytocola oryzae sp. nov.}

Actinophytocola oryzae (o.ry'zae. L. n. oryza rice and also the name of a botanical genus; L. gen. n. oryzae of rice, denoting the isolation of the type strain from roots of Thai glutinous rice plants).

In addition to the characteristics given in the genus description, has the following properties. Grows well on ISP 3 and oatmeal-nitrate agar and grows moderately on ISP 2 and 1/10 yeast extract-starch agar, but grows poorly on ISP 4 and ISP 5. Pale peach $(5 \mathrm{ca})$ aerial mycelium is produced on ISP 3 and substrate mycelium is light melon yellow (3ea); no soluble pigment is produced. A trace of rust tan (5le) soluble pigment is produced on oatmealnitrate agar. No aerial mycelium is observed on ISP 2 or $1 / 10$ yeast extract starch agar. Does not grow on ISP 9 or ISP 6. Temperature range for growth is $12-30{ }^{\circ} \mathrm{C}$, with optimal growth at $18-28{ }^{\circ} \mathrm{C}$. Grows at $\mathrm{pH} 5.0-10.0$, with optimal growth at $\mathrm{pH} 6.0-7.0$. Tolerates up to $2 \% \mathrm{NaCl}$. Negative for reduction of nitrate and production of melanin pigments and $\mathrm{H}_{2} \mathrm{~S}$. Catalase-positive and oxidase-negative. Degrades starch, but negative for decomposition of benzoate, hypoxanthine, xanthine and milk. Liquefaction of gelatin is weakly positive. Degradation of 
citrate is positive. D-Fructose, D-glucose and L-rhamnose can be utilized as sole carbon sources, but L-arabinose, dulcitol, D-galactose, myo-inositol, lactose, maltose, Dmannitol, D-mannose, raffinose, D-sorbitol, sucrose, trehalose and D-xylose are not utilized. Produces acid from L-arabinose, D-fructose and D-glucose, but not from adonitol, dulcitol, erythritol, D-galactose, myo-inositol, lactose, D-mannitol, raffinose or L-rhamnose.

The type strain is GMKU $367^{\mathrm{T}}\left(=\mathrm{BCC} 31372^{\mathrm{T}}=\mathrm{NBRC}\right.$ $\left.105245^{\mathrm{T}}\right)$, isolated from roots of Thai glutinous rice plants (Oryza sativa L. 'RD6') collected from Pathum Thani Rice Research Center, Pathum Thani province, Thailand.

\section{Acknowledgements}

We give special thanks to Professor Pradit Pongtongkam for providing the rice cultivar. C.I. was awarded a $\mathrm{PhD}$ scholarship from the Commission on Higher Education, Ministry of Education, Thailand. This study was supported by the Thailand Research Fund, the Commission on Higher Education, and Kasetsart University Research and Development Institute.

\section{References}

Becker, B., Lechevalier, M. P. \& Lechevalier, H. A. (1965). Chemical composition of cell-wall preparations from strains of various formgenera of aerobic actinomycetes. Appl Microbiol 13, 236-243.

Collins, M. D., Pirouz, T., Goodfellow, M. \& Minnikin, D. E. (1977). Distribution of menaquinones in actinomycetes and corynebacteria. J Gen Microbiol 100, 221-230.

Eck, R. V. \& Dayhoff, M. O. (1966). Atlas of Protein Sequence and Structure. Silver Springs, MD: National Biomedical Research Foundation.

Embley, M. T., Smida, J. \& Stackebrandt, E. (1988). The phylogeny of mycolate-less wall chemotype IV actinomycetes and description of Pseudonocardiaceae fam. nov. Syst Appl Microbiol 11, 44-52.

Felsenstein, J. (1981). Evolutionary trees from DNA sequences: a maximum likelihood approach. J Mol Evol 17, 368-379.

Felsenstein, J. (1985). Confidence limits on phylogenies: an approach using the bootstrap. Evolution 39, 783-791.

Gordon, R. E., Barnett, D. A., Handerhan, J. E. \& Pang, C. H.-N. (1974). Nocardia coeliaca, Nocardia autotrophica, and the nocardin strain. Int J Syst Bacteriol 24, 54-63.

Hasegawa, T., Takizawa, M. \& Tanida, S. (1983). A rapid analysis for chemical grouping of aerobic actinomycetes. J Gen Appl Microbiol 29, 319-322.

Hayakawa, M. \& Nonomura, H. (1987). Humic acid-vitamin agar, a new medium for selective isolation of soil actinomycetes. J Ferment Technol 65, 501-509.

Henssen, A. (1957). Beiträge zur Morphologie und Systematik der thermophilen Actinomyceten. Arch Mikrobiol 26, 373-414 (in German)

Hobbs, G., Frazer, C. M., Gardner, D. C. J., Cullum, J. A. \& Oliver, S. G. (1989). Dispersed growth of Streptomyces in liquid culture. Appl Microbiol Biotechnol 31, 272-277.

Huang, Y., Wang, L., Lu, Z., Hong, L., Liu, Z., Tan, G. Y. A. \& Goodfellow, M. (2002). Proposal to combine the genera Actinobispora and Pseudonocardia in an emended genus Pseudonocardia, and description of Pseudonocardia zijingensis sp. nov. Int J Syst Evol Microbiol 52, 977-982.
Jacobson, E., Granville, W. C. \& Foss, C. E. (1958). Color Harmony Manual, 4th edn. Chicago: Container Corporation of America.

Jiang, Y., Wiese, J., Tang, S. K., Xu, L. H., Imhoff, J. F. \& Jiang, C. L. (2008). Actinomycetospora chiangmaiensis gen. nov., sp. nov., a new member of the family Pseudonocardiaceae. Int J Syst Evol Microbiol 58, 408-413.

Kataoka, M., Ueda, K., Kudo, T., Seki, T. \& Yoshida, T. (1997). Application of the variable region in 16S rDNA to create an index for rapid species identification in the genus Streptomyces. FEMS Microbiol Lett 151, 249-255.

Kieser, Y., Bibb, M. J., Buttner, M. J., Chater, K. F. \& Hopwood, D. A. (2000). Practical Streptomyces Genetics. Norwich: The John Innes Foundation.

Kim, S. B. \& Goodfellow, M. (1999). Reclassification of Amycolatopsis rugosa Lechevalier et al. 1986 as Prauserella rugosa gen. nov., comb. nov. Int J Syst Bacteriol 49, 507-512.

Kimura, M. (1980). A simple method for estimating evolutionary rates of base substitutions through comparative studies of nucleotide sequences. J Mol Evol 16, 111-120.

Korn-Wendisch, F., Kempf, A., Grund, E., Kroppenstedt, R. M. \& Kutzner, H. J. (1989). Transfer of Faenia rectivirgula Kurup and Agre 1983 to the genus Saccharopolyspora Lacey and Goodfellow 1975, elevation of Saccharopolyspora hirsuta subsp. taberi Labeda 1987 to species level, and emended description of the genus Saccharopolyspora. Int J Syst Bacteriol 39, 430-441.

Korn-Wendisch, F., Rainey, F., Kroppenstedt, R. M., Kempf, A., Majazza, A., Kutzner, H. J. \& Stackebrandt, E. (1995). Thermocrispum gen. nov., a new genus of the order Actinomycetales, and description of Thermocrispum municipale sp. nov. and Thermocrispum agreste sp. nov. Int J Syst Bacteriol 45, 67-77.

Küster, E. \& Williams, S. T. (1964). Selection of media for isolation of streptomycetes. Nature 202, 928-929.

Labeda, D. P. (2001). Crossiella gen. nov., a new genus related to Streptoalloteichus. Int J Syst Evol Microbiol 51, 1575-1579.

Labeda, D. P. \& Kroppenstedt, R. M. (2008). Proposal for the new genus Allokutzneria gen. nov. within the suborder Pseudonocardineae and transfer of Kibdelosporangium albatum Tomita et al. 1993 as Allokutzneria albata comb. nov. Int J Syst Evol Microbiol 58, 14721475.

Labeda, D. P., Kroppenstedt, R. M., Euzéby, J. P. \& Tindall, B. J. (2008). Proposal of Goodfellowiella gen. nov. to replace the illegitimate genus name Goodfellowia Labeda and Kroppenstedt 2006. Int J Syst Evol Microbiol 58, 1047-1048.

Lacey, J. \& Goodfellow, M. (1975). A novel actinomycete from sugarcane bagasse: Saccharopolyspora hirsuta gen. et sp. nov. J Gen Microbiol 88, 75-85.

Larkin, M. A., Blackshields, G., Brown, N. P., Chenna, R., McGettigan, P. A., McWilliam, H., Valentin, F., Wallace, I. M., Wilm, A. \& other authors (2007). Clustal W and Clustal X version 2.0. Bioinformatics 23, 2947-2948.

Lechevalier, M. P., De Bièvre, C. \& Lechevalier, H. A. (1977). Chemotaxonomy of aerobic actinomycetes: phospholipid composition. Biochem Syst Ecol 5, 249-260.

Lechevalier, M. P., Prauser, H., Labeda, D. P. \& Ruan, J. S. (1986). Two new genera of nocardioform actinomycetes: Amycolata gen. nov. and Amycolatopsis gen. nov. Int J Syst Bacteriol 36, 29-37.

Lee, S. D. \& Hah, Y. C. (2001). Amycolatopsis albidoflavus sp. nov. Int J Syst Evol Microbiol 51, 645-650.

Nonomura, H. \& Ohara, Y. (1971). Distribution of actinomycetes in soil. $\mathrm{X}$. New genus and species of monosporic actinomycetes. J Ferment Technol 49, 895-903. 
Park, S. W., Park, S. T., Lee, J. E. \& Kim, Y. M. (2008). Pseudonocardia carboxydivorans sp. nov., a carbon monoxide-oxidizing actinomycete, and an emended description of the genus Pseudonocardia. Int J Syst Evol Microbiol 58, 2475-2478.

Perrière, G. \& Gouy, M. (1996). WWW-Query: an on-line retrieval system for biological sequence banks. Biochimie 78, 364-369.

Reichert, K., Lipski, A., Pradella, S., Stackebrandt, E. \& Altendorf, K. (1998). Pseudonocardia asaccharolytica sp. nov. and Pseudonocardia sulfidoxydans sp. nov., two new dimethyl disulfide-degrading actinomycetes and emended description of the genus Pseudonocardia. Int $J$ Syst Bacteriol 48, 441-449.

Saitou, N. \& Nei, M. (1987). The neighbor-joining method: a new method for reconstructing phylogenetic trees. Mol Biol Evol 4, 406425.

Sasser, M. (1990). Identification of bacteria by gas chromatography of cellular fatty acids, MIDI Technical Note 101. Newark, DE: MIDI Inc.

Schleifer, K. H. \& Kandler, O. (1972). Peptidoglycan types of bacterial cell walls and their taxonomic implications. Bacteriol Rev 36, 407-477.

Shearer, M. C., Colman, P. M., Ferrin, R. M., Nisbet, L. J. \& Nash, C. H. (1986). New genus of the Actinomycetales: Kibdelosporangium aridum gen. nov., sp. nov. Int J Syst Bacteriol 36, 47-54.

Shirling, E. B. \& Gottlieb, D. (1966). Methods for characterization of Streptomyces species. Int J Syst Bacteriol 16, 313-340.

Stackebrandt, E., Kroppenstedt, R. M., Jahnke, K.-D., Kemmerling, C. \& Gürtler, H. (1994). Transfer of Streptosporangium viridogriseum (Okuda et al. 1966), Streptosporangium viridogriseum subsp. kofuense (Nonomura and Ohara 1969), and Streptosporangium albidum (Furumai et al. 1968) to Kutzneria gen. nov. as Kutzneria viridogrisea comb. nov., Kutzneria kofuensis comb. nov., and Kutzneria albida comb. nov., respectively, and emendation of the genus Streptosporangium. Int J Syst Bacteriol 44, 265-269.

Stackebrandt, E., Rainey, F. A. \& Ward-Rainey, N. L. (1997). Proposal for a new hierarchic classification system, Actinobacteria classis nov. Int J Syst Bacteriol 47, 479-491.
Tamaoka, J. \& Komagata, K. (1984). Determination of DNA base composition by reversed-phase high-performance liquid chromatography. FEMS Microbiol Lett 25, 125-128.

Tamaoka, J., Katayama-Fujimura, Y. \& Kuraishi, H. (1983). Analysis of bacterial menaquinone mixtures by high performance liquid chromatography. J Appl Bacteriol 54, 31-36.

Tamura, T., Liu, Z., Zhang, Y. \& Hatano, K. (2000). Actinoalloteichus cyanogriseus gen. nov., sp. nov. Int J Syst Evol Microbiol 50, 14351440.

Tamura, K., Dudley, J., Nei, M. \& Kumar, S. (2007). MEGA4: molecular evolutionary genetics analysis (MEGA) software version 4.0. Mol Biol Evol 24, 1596-1599.

Tian, X. P., Zhi, X. Y., Qiu, Y. Q., Zhang, Y. Q., Tang, S. K., Xu, L. H., Zhang, S. \& Li, W. J. (2009). Sciscionella marina gen. nov., sp. nov., a marine actinomycete isolated from a sediment in the northern South China Sea. Int J Syst Evol Microbiol 59, 222-228.

Tomita, K., Nakakita, Y., Hoshino, Y., Numata, K. \& Kawaguchi, H. (1987). New genus of the Actinomycetales: Streptoalloteichus hindustanus gen. nov., nom. rev.; sp. nov., nom. rev. Int J Syst Bacteriol 37, 211-213.

Tomiyasu, I. (1982). Mycolic acid composition and thermally adaptative changes in Nocardia asteroides. J Bacteriol 151, 828-837.

Uchida, K. \& Aida, K. (1984). An improved method for the glycolate test for simple identification of acyl type of bacterial cell walls. J Gen Appl Microbiol 30, 131-134.

Wang, Y., Zhang, Z. \& Ruan, J. S. (1996). A proposal to transfer Microbispora bispora (Lechevalier 1965) to a new genus, Thermobispora gen. nov., as Thermobispora bispora comb. nov. Int J Syst Bacteriol 46, 933-938.

Warwick, S., Bowen, T., McVeigh, H. \& Embley, T. M. (1994). A phylogenetic analysis of the family Pseudonocardiaceae and the genera Actinokineospora and Saccharothrix with 16S rRNA sequences and a proposal to combine the genera Amycolata and Pseudonocardia in an emended genus Pseudonocardia. Int J Syst Bacteriol 44, 293-299. 